\title{
Antioxidative Potential of a Streptomyces sp. MUM292 Isolated from Mangrove Soil
}

\author{
Loh Teng-Hern Tan $\mathbb{D}^{\mathbb{D}},{ }^{1,2,3}$ Kok-Gan Chan $\mathbb{D}^{4,}{ }^{4,5}$ Chim Kei Chan, \\ Tahir Mehmood Khan $\left(\mathbb{C}^{1,2,7,8}\right.$ Learn-Han Lee ${ }^{10},,^{1,2,8,9}$ and Bey-Hing Goh $(\mathbb{1})$ 1,2,8,9 \\ ${ }^{1}$ Novel Bacteria and Drug Discovery (NBDD) Research Group, School of Pharmacy, Monash University Malaysia, \\ 47500 Bandar Sunway, Selangor Darul Ehsan, Malaysia \\ ${ }^{2}$ Biofunctional Molecule Exploratory Research Group (BMEX), School of Pharmacy, Monash University Malaysia, \\ Bandar Sunway, Selangor Darul Ehsan, Malaysia \\ ${ }^{3}$ Biomedical Research Laboratory, Jeffrey Cheah School of Medicine and Health Sciences, Monash University Malaysia, \\ Bandar Sunway, Selangor Darul Ehsan, Malaysia \\ ${ }^{4}$ International Genome Centre, Jiangsu University, Zhenjiang, China \\ ${ }^{5}$ Division of Genetics and Molecular Biology, Institute of Biological Sciences, Faculty of Science, University of Malaya, \\ 50603 Kuala Lumpur, Malaysia \\ ${ }^{6}$ Biomolecular Research Group, Biochemistry Program, Institute of Biological Sciences, Faculty of Science, University of Malaya, \\ Kuala Lumpur, Malaysia \\ ${ }^{7}$ The Institute of Pharmaceutical Sciences, University of Veterinary and Animal Sciences, Lahore, Pakistan \\ ${ }^{8}$ Asian Centre for Evidence Synthesis in Population, Implementation and Clinical Outcomes, Health and Well-Being Cluster, \\ Global Asia in the 21st Century Platform, Monash University Malaysia, Bandar Sunway, Selangor Darul Ehsan, Malaysia \\ ${ }^{9}$ Center of Health Outcomes Research and Therapeutic Safety, School of Pharmaceutical Sciences, University of Phayao, \\ Phayao, Thailand
}

Correspondence should be addressed to Learn-Han Lee; lee.learn.han@monash.edu and Bey-Hing Goh; goh.bey.hing@monash.edu

Received 13 October 2017; Revised 27 January 2018; Accepted 20 February 2018; Published 1 April 2018

Academic Editor: Ramesh C. Ray

Copyright (C) 2018 Loh Teng-Hern Tan et al. This is an open access article distributed under the Creative Commons Attribution License, which permits unrestricted use, distribution, and reproduction in any medium, provided the original work is properly cited.

Mangrove derived microorganisms constitute a rich bioresource for bioprospecting of bioactive natural products. This study explored the antioxidant potentials of Streptomyces bacteria derived from mangrove soil. Based on 16S rRNA phylogenetic analysis, strain MUM292 was identified as the genus Streptomyces. Strain MUM292 showed the highest 16S rRNA gene sequence similarity of $99.54 \%$ with S. griseoruber NBRC12873 ${ }^{\mathrm{T}}$. Furthermore, strain MUM292 was also characterized and showed phenotypic characteristics consistent with Streptomyces bacteria. Fermentation and extraction were performed to obtain the MUM292 extract containing the secondary metabolites of strain MUM292. The extract displayed promising antioxidant activities, including DPPH, ABTS, and superoxide radical scavenging and also metal-chelating activities. The process of lipid peroxidation in lipid-rich product was also retarded by MUM292 extract and resulted in reduced MDA production. The potential bioactive constituents of MUM292 extract were investigated using GC-MS and preliminary detection showed the presence of pyrazine, pyrrole, cyclic dipeptides, and phenolic compound in MUM292 extract. This work demonstrates that Streptomyces MUM292 can be a potential antioxidant resource for food and pharmaceutical industries.

\section{Introduction}

Antioxidants function to exert protective effect on human health from oxidative damage caused by reactive oxygen species (ROS) [1, 2]. The ROS such as hydroxyl, superoxide, and peroxyl radicals attack macromolecules including membrane lipids, proteins, and DNA [3] which subsequently lead to serious health complications such as cancer, diabetes 
mellitus, and neurodegenerative and chronic inflammatory diseases [4-7]. ROS has also been identified to be responsible for deterioration of food products through lipid oxidation [8]. Generally, lipid oxidation occurs during processing, distribution, and storage of food products, thus negatively affecting the food quality, shelf life, and safety. Besides promoting oxidative rancidity, lipid oxidation can lead to loss of fat-soluble vitamins and essential fatty acids as well as generation of undesirable secondary lipid peroxidation products with toxic and carcinogenic effects [9]. In order to retard oxidation and peroxidation processes, several synthetic antioxidants such as butylated hydroxytoluene (BHT), butylated hydroxyanisole (BHA), tert-butylhydroquinone (TBHQ), and propyl gallate (PG) have been used by food and pharmaceutical industries for the last century [10]. However, the use of these synthetic antioxidants have been associated with potential health hazards such as liver damage and carcinogenesis [11]. Thus, the concerns over the toxicity of synthetic antioxidants have provided an impetus to search for new and safe antioxidants as alternatives to protect cell in human body against oxidative damage as well as to stabilize fats against oxidative rancidity in food products.

Recently, there is a considerable interest in the food industry as well as pharmaceutical industry for the development of antioxidants derived from natural sources, including plants, animals, and microorganisms [12, 13]. Natural products are rich sources of structurally diverse chemical entities with valuable nutraceutical, pharmaceutical, and cosmeceutical applications $[14,15]$. Among them, microbes represent one of the richest sources of bioactive natural products [16]. Microbes have been recognized for their potential in the bioprocess technologies, demonstrating significant advantages over plant extraction and chemical synthesis methods. The advantages of rapid growth rates and ease of cultivation demonstrated by microbial biofactories are believed to provide unhindered production of desirable compounds and meet the increasing demand from the ever growing world population [17]. Furthermore, microbial biofactories constitute relatively environmental friendly methodologies [18] and, therefore, are preferred alternatives for overcoming serious environmental problems posed by conventional chemical synthesis methodologies.

Streptomyces are Gram-positive filamentous bacteria that produce a wide variety of bioactive compounds including antibiotics, antifungal, antitumor, and immunosuppressant agents which are important in pharmaceutical and agricultural industries [19-21]. The reasons of being an unparalleled source of diverse chemical entities are well explained by the large genome size harbored by these microorganisms [22] and the possession of a number of biosynthetic gene clusters that encode multifunctional biosynthetic enzymes, which enables the synthesis of highly complex secondary metabolites [23]. In fact, majority of the microbial natural products that have been developed into clinical drugs available in the market are produced by the genus Streptomyces [24, 25].

Mangrove forests are located in intertidal regions along tropical and subtropical shores. Mangroves are among the most productive natural ecosystems known, serving as imperative sources of supply for food, medicines, and building materials [26]. Given the constant exposure to extremely dynamic environmental conditions in the mangrove, it is believed that organisms have acquired various antioxidant defense systems to adapt and survive in the mangrove habitat $[27,28]$. In addition, these environmental stressors like the fluctuation of salinity and tidal gradients are also thought to drive the microorganism's metabolic pathways toward production of unprecedented natural products with wide array of bioactivities $[29,30]$. Furthermore, along with the recent isolation of novel Streptomyces species from mangrove soil such as $S$. colonosanans [31], S. antioxidans [32], S. malaysiense [32], S. humi [33], and S. euryhalinus [34], numerous mangrove derived Streptomyces spp. were shown previously to produce antioxidants $[31,35,36]$. Thus, mangrove derived Streptomyces portrays an important reservoir for bioprospecting of novel and interesting chemical scaffolds with bioactivities. In the present study, the antioxidant potentials of a Streptomyces strain isolated from mangrove soil were examined for its radicals scavenging and metalchelating activities. In addition, this study also reported the potential of the extract of the strain in suppressing lipid peroxidation in lipid-rich food product.

\section{Materials and Methods}

2.1. Soil Sampling. The mangrove soil sampling was performed at the mangrove forest Kuala Selangor, Malaysia, located at the coordinates $3^{\circ} 21^{\prime} 45.8^{\prime \prime} \mathrm{N}$ and $101^{\circ} 18^{\prime} 4.5^{\prime \prime} \mathrm{E}$. The sample was sampled to 20-centimeter deep soil layer (after removing 2- to 3-centimeter surface layer). The collected soil was kept at $-20^{\circ} \mathrm{C}$ before processing.

2.2. Isolation and Maintenance of Strain MUM292. The soil sample was pounded and treated with wet heat method [48]. Serial dilution of the treated soil sample with sterile water was performed prior to spread plate on ISP2 agar added with cycloheximide $(25 \mu \mathrm{g} / \mathrm{ml})$ and nystatin $(10 \mu \mathrm{g} / \mathrm{ml})$ [49]. The spread plate ISP2 agar was incubated at $28^{\circ} \mathrm{C}$ for 2 weeks. Pure colony of strain MUM292 was selected and purified with new ISP2 agar. For maintenance of strain MUM292, slants of ISP2 agar were prepared and stored at $28^{\circ} \mathrm{C}$ and stored in $20 \%(\mathrm{v} / \mathrm{v})$ glycerol suspensions at $-20^{\circ} \mathrm{C}$ for longer term preservation.

2.3. Phylogenetic Identification of Strain MUM292. Total genomic DNA was extracted from strain MUM292 as described by Hong et al. [29]. The 16S rRNA gene was amplified from the genomic DNA by PCR [50] using 27F-1492R primers [51]. The sequences of the 16S rRNA primer pair used are 27F ( $5^{\prime}$-GTTTGATCCTGGCTCAG- $3^{\prime}$ ) and 1492R ( $5^{\prime}$-TACGGCTACCTTGTTACGACTT-3'). The PCR reaction was performed according to Lee et al. [50]. The obtained 16S rRNA gene sequence was aligned and compared with representative gene sequences of related type strains of the genus Streptomyces retrieved from the GenBank/EMBL/DDBJ databases using CLUSTAL-X software [52]. A neighbour-joining phylogenetic tree was constructed using MEGA version 6.0 software [53, 54]. Kimura's two-parameter model was used compute the evolutionary distances for the neighbour-joining algorithm [55]. The 
EzTaxon-e server (https://www.ezbiocloud.net/) was used to determine sequence similarity [56]. The bootstrap value was measured based on 1000-resampling method of Felsenstein [57] to evaluate the stability of the resultant trees topologies.

2.4. Phenotypic Characterization of Strain MUM292. A series of agar media was used to investigate the morphology and cultural characteristic of strain MUM292. The agar media were the International Streptomyces Project (ISP) 2, ISP3, ISP4, ISP5, ISP6, ISP7 [49], actinomycetes isolation agar (AIA) [58], starch casein agar (SCA) [59], and nutrient agar [60]. After incubation at $28^{\circ} \mathrm{C}$ for 14 days, the morphology and color of strain MUM292 colony were examined by comparing to ISCC-NBS color charts [61]. Microscopic evaluation of strain MUM292 was performed using scanning electron microscopy (TM-1000, Hitachi). The tolerance of strain MUM292 toward different temperature (4 to $40^{\circ} \mathrm{C}$ ), salinity ( 0 to $10 \%(\mathrm{w} / \mathrm{v})$ ), and $\mathrm{pH}(0$ to 10$)$ was examined for 2 weeks. The ability of strain MUM292 to produce melanoid pigments was assessed on ISP7 agar. Hemolytic activity was evaluated using blood agar [62]. The enzyme productivity of strain MUM292 was examined on ISP2 agar added with respective substrates (starch, carboxymethyl cellulose, chitin, tributyrin, casein, and xylan) [51, 63]. The susceptibility pattern of strain MUM292 to antibiotics was determined by the disc diffusion method $[50,64]$. The antibiotic discs [ampicillin $(10 \mu \mathrm{g})$, ampicillin sulbactam $(30 \mu \mathrm{g})$, cefotaxime $(30 \mu \mathrm{g})$, cefuroxime $(30 \mu \mathrm{g})$, cephalosporin $(30 \mu \mathrm{g})$, chloramphenicol $(30 \mu \mathrm{g})$, ciprofloxacin $(10 \mu \mathrm{g})$, erythromycin $(15 \mu \mathrm{g})$, gentamicin $(20 \mu \mathrm{g})$, nalidixic acid $(30 \mu \mathrm{g})$, Penicillin $\mathrm{G}(10 \mu \mathrm{g})$, streptomycin $(10 \mu \mathrm{g})$, tetracycline $(30 \mu \mathrm{g})$, and vancomycin $(30 \mu \mathrm{g})$ ] (Oxoid, Basingstoke, UK) were placed aseptically and monitored for zone of inhibition after 1 to 2 weeks of incubation at $28^{\circ} \mathrm{C}$. The carbon source utilization and chemical sensitivity of strain MUM292 were investigated using Biolog GenIII MicroPlates (Biolog, USA).

2.5. Fermentation and Preparation of MUM292 Extract. Submerged fermentation was performed using Han's Fermentation Media 1 (HFM1) (Biomerge, Malaysia) in $250 \mathrm{~mL}$ Erlenmeyer flasks [29, 65]. A fourteen-day broth culture of strain MUM292 was inoculated into the autoclaved and cooled HFM1. The flasks were incubated on a rotary shaker at $200 \mathrm{rpm}$ at $28^{\circ} \mathrm{C}$ for 10 days. After fermentation, the supernatant was collected by being centrifuged at $12,000 \times \mathrm{g}$ for $15 \mathrm{~min}\left(4^{\circ} \mathrm{C}\right)$ and filtered using filter paper (Whatman, UK). The freeze-dried product was extracted with methanol for 72 hours before being removed by rotary evaporation at $40^{\circ} \mathrm{C}$ to obtain the MUM292 extract. The extract was constituted in dimethyl sulphoxide (DMSO) before use for antioxidant assays.

\subsection{Antioxidant Activities of MUM292 Extract}

2.6.1. DPPH Radical Scavenging Activity. The scavenging activity of MUM292 extract on DPPH radical was measured as described by Tan et al. [35]. DPPH radical $0.016 \%(\mathrm{w} / \mathrm{v})$ was prepared with $95 \%(\mathrm{v} / \mathrm{v})$ ethanol before reacting with MUM292 extract. The MUM292 extract was left to react with
DPPH radical in the dark at room temperature for 20 min. The resultant absorbance of DPPH radical was measured by microplate reader at $515 \mathrm{~nm}$. Gallic acid was used as the positive control.

2.6.2. Superoxide Anion Scavenging Activity. An indirect colorimetric method was utilized to assess the superoxide anion scavenging activity of MUM292 extract (19160 SOD Assay Kit-WST, Sigma Aldrich). The assay determines reduction of the (2-(4-iodophenyl)-3-(4-nitrophenyl)-5-(2,4disulfophenyl)-2H-tetrazolium, monosodium salt) (WST-1) by superoxide anion into water soluble formazan dye which can be measured colorimetrically. Based on the protocol (Sigma Aldrich, USA), MUM292 extract was added with respective reagents accordingly and incubated at $37^{\circ} \mathrm{C}$ for $30 \mathrm{~min}$. The resultant absorbance of the formazan dye was measured by microplate reader at $450 \mathrm{~nm}$.

2.6.3. ABTS Radical Scavenging Activity. The ability of MUM292 extract to scavenge 2,2' -azino-bis(3-ethylbenzothiazoline-6-sulphonic acid) (ABTS) radical was assessed according to the protocol described in Tan et al. [35]. ABTS radical cation (ABTS ${ }^{*}$ ) was generated by reacting ABTS stock solution $(7 \mathrm{mM})$ with potassium persulphate $(2.45 \mathrm{mM})$ overnight. The MUM292 extract was reacted with ABTS radical in the dark at room temperature for $20 \mathrm{~min}$. The resultant absorbance of DPPH radical was measured by microplate reader at $734 \mathrm{~nm}$. Gallic acid was used as a positive control.

2.6.4. Metal-Chelating Activity. MUM292 extract was investigated for its ability to chelate metal ion by using protocol as described previously $[66,67]$. The metal-chelating activity of MUM292 extract was determined by measuring the reduction of red color complexes between ferrous ion and ferrozine due to the presence of metal chelators. Briefly, MUM292 extract was mixed with $\mathrm{FeSO}_{4}(2 \mathrm{mM})$ prior to addition of ferrozine $(5 \mathrm{mM})$ for $10 \mathrm{~min}$ at room temperature. The absorbance of the mixtures was measured by microplate reader at $562 \mathrm{~nm}$. EDTA was used as a positive control.

2.7. Lipid Peroxidation Assay. The inhibitory effect of MUM292 extract against lipid peroxidation was investigated by quantifying the malondialdehyde (MDA) formed from iron-induced lipid peroxidation in lipid-rich media [68]. MUM292 extract was mixed and added to $800 \mu \mathrm{L} \mathrm{10 \%} \mathrm{(v/v)}$ egg homogenate prepared in phosphate buffered saline and incubated at $37^{\circ} \mathrm{C}$ for 1 hour together with $100 \mu \mathrm{M}$ of $\mathrm{FeSO}_{4}$ to initiate lipid peroxidation. Ice-cold 20\% trichloroacetic acid was added in 1:1 ratio to halt the reaction. The MDA content in the supernatant was collected after centrifugation at $1,200 \times \mathrm{g}$ for $10 \mathrm{~min}$ and measured by using thiobarbituric acid reactive species (TBARS) assay [35]. Fluorometer (Perkin Elmer, USA) was used to measure the fluorescent product at 535 excitations $/ 553 \mathrm{~nm}$ emission.

2.8. Total Phenolic and Flavonoid Content Determination. Folin-Ciocalteu's reagent method was used to estimate the total phenolic content (TPC) of MUM292 extract in 96-well 
plate [69]. Briefly, $10 \mu \mathrm{L}$ of samples was mixed with $50 \mu \mathrm{L}$ of $(1: 10)$ diluted Folin-Ciocalteu's reagent and incubated for $5 \mathrm{~min}$ in the dark. Forty microliters of $7.5 \% \mathrm{Na}_{2} \mathrm{CO}_{3}$ was added to all well and incubated for $30 \mathrm{~min}$ at room temperature. The absorbance of each well was measured at $750 \mathrm{~nm}$ using microplate reader. Aluminium-flavonoid complexes formation method was used to estimate the total flavonoid content of MUM292 extract in 96 well-microplate [70]. The absorbance of the resulting mixture was measured at $510 \mathrm{~nm}$ using microplate reader.

2.9. Gas Chromatography-Mass Spectrometry (GC-MS) Anal$y$ sis. GC-MS analysis was performed to profile the potential bioactive compounds present in MUM292 extract according to Supriady et al. [71]. The analysis was conducted using the Agilent Technologies 6980N (GC) equipped with 5979 Mass Selective Detector (MS), HP-5MS (5\% phenyl methyl siloxane) capillary column of dimensions $30.0 \mathrm{~m} \times 250 \mu \mathrm{m}$ $\times 0.25 \mu \mathrm{m}$ and helium as carrier gas at $1 \mathrm{~mL} / \mathrm{min}$. For the initial $10 \mathrm{~min}$, the temperature of column was maintained at $40^{\circ} \mathrm{C}$. The temperature was then increased by $3^{\circ} \mathrm{C} / \mathrm{min}$ until $250^{\circ} \mathrm{C}$ and kept isothermally for $5 \mathrm{~min}$. The MS was operating at $70 \mathrm{eV}$. The mass spectra of detected chemical constituents were compared to those available from W9N11 MS library.

2.10. Statistical Analysis. Each measurement was performed at least in triplicate. The significant difference between the treated and untreated groups was determined by one-way analysis of variance (ANOVA) and Tukey's post hoc analysis using SPSS software 20. A difference was considered statistically significant when $p \leq 0.05$. Pearson's correlation analysis was used to determine the relationship between the TPC and the antioxidant activity of the extract.

\section{Results and Discussion}

The highly adapted mangrove derived microbes represent a biomedical resource of unprecedented magnitude but hold great promise, as evidenced by the numerous novel or unusual mangrove-associated microbial metabolites [28]. Being the prolific producer of bioactive metabolites, Streptomyces sp. has produced numerous FDA-approved drugs [72, 73]. Given that the mangrove-associated microbes are constantly exposed to many natural stressors, they are believed to have developed specific antioxidant defense mechanism to fight against oxidative stress, perhaps by producing antioxidative metabolites $[29,30]$. Thus, the goal of this study is to explore the antioxidant potentials of Streptomyces sp. from underexplored environments such as the mangrove sediments.

3.1. 16S rRNA PCR and Phylogenetic Analysis. This study has isolated strain MUM292 which is identified as Streptomyces sp. based on 16S rRNA gene phylogenetic analysis from mangrove soil sample. A $1319 \mathrm{bp}$ nearly complete 16S rRNA gene sequence of MUM292 was obtained from the sequencing. Using CLUSTAL-X software, gene sequence alignment was performed between the 16S rRNA gene sequences of strain MUM292 and the type strains of representative members of the genus Streptomyces retrieved from GenBank/EMBL/DDBJ databases. Phylogenetic tree was constructed based on the $16 \mathrm{~S}$ rRNA gene sequences and showed that strain MUM292 (Figure 1) formed a distinct clade with S. griseoruber NBRC12873 ${ }^{\mathrm{T}}$ at bootstrap value of $66 \%$. The strain MUM292 exhibits highest 16S rRNA gene sequence similarity to S. griseoruber NBRC12873 ${ }^{\mathrm{T}}$ (99.54\%) and S. curacoi NRRL B-2901 (99.09\%) and S. cellostaticus NBRC12849 ${ }^{\mathrm{T}}(98.86 \%)$. In addition, the phylogenetic analysis also suggested that strain MUM292 may possess the potential to produce bioactive compounds since it is clustered together with S. griseoruber which was known to synthesize numerous bioactive metabolites [74, 75].

3.2. Phenotypic Characterization of Strain MUM292. Strain MUM292 is Gram-positive and aerobic. Morphologically, strain MUM292 forms colony with different color of aerial and substrate mycelium on different solid media. It has olive brown color substrate mycelium and pale greenish yellow aerial mycelium when grown on ISP2 agar. At $28^{\circ} \mathrm{C}$, strain MUM292 grows on ISP2 and NA agar and poorly on ISP3, ISP5, ISP6, ISP7, AIA, and SCA. However, no growth was observed on ISP4 agar. Furthermore, strain MUM292 appears as smooth and dense network of filaments under the scanning electron microscopy (Figure 2). Strain MUM292 is able to tolerate $\mathrm{pH} 6$ and $\mathrm{pH} 8$ (optimum at $\mathrm{pH} 7$ ), 0 to $2 \%$ of $\mathrm{NaCl}$ concentration (optimum 2\%), and 24 to $36^{\circ} \mathrm{C}$ (optimum at $32^{\circ} \mathrm{C}$ ). Strain MUM292 is catalasepositive but does not induce hemolysis (Figure 3). Strain MUM292 is also negative for melanoid pigment production. The enzymatic tests showed that strain MUM292 is capable of producing amylase and cellulase enzymes that digest soluble starch and carboxymethylcellulose (CMC), respectively. But, strain MUM292 showed negative production of enzymes that degrade tributyrin, casein, xylan, and chitin.

The secondary metabolism of Streptomyces sp. is greatly influenced by the availability of carbon and nitrogen sources; thereby the types and quantity of the metabolites produced are dependent on the composition of substrates given/available for the bacteria during growth [76]. In order to achieve an overview of strain MUM292 metabolic profile, we utilized the Biolog GEN III MicroPlate system to evaluate its ability in utilizing different types of carbon and nitrogen sources. The Biolog results indicated that strain MUM292 showed positive utilization of carbon source from acetic acid, acetoacetic acid, a-D-glucose, a-D-lactose, a-hydroxybutyric acid, a-keto-glutaric acid, b-hydroxyl-D,L-butyric acid, bromo-succinic acid, D-aspartic acid, D-cellobiose, dextrin, D-fructose, D-fructose-6-phosphate, D-galactose, D-galacturonic acid, D-gluconic acid, D-glucose-6-PO4Dglucuronic acid, D-lactic acid methyl ester, D-malic acid, D-maltose, D-mannose, D-melibiose, D-raffinose, D-saccharic acid, D-serine, D-trehalose, formic acid, gelatin, glucuronamide, glycerol, glycyl-L-proline, L-alanine, Laspartic acid, L-glutamic acid, L-histidine, L-lactic acid, L-malic acid, L-pyroglutamic acid, L-rhamnose, L-serine, $\mathrm{N}$-acetyl-D-glucosamine, pectin, p-hydroxy-phenylacetic acid, propionic acid, quinic acid, sucrose, Tween 40, and y-amino-butyric acid. Meanwhile, strain MUM292 does 


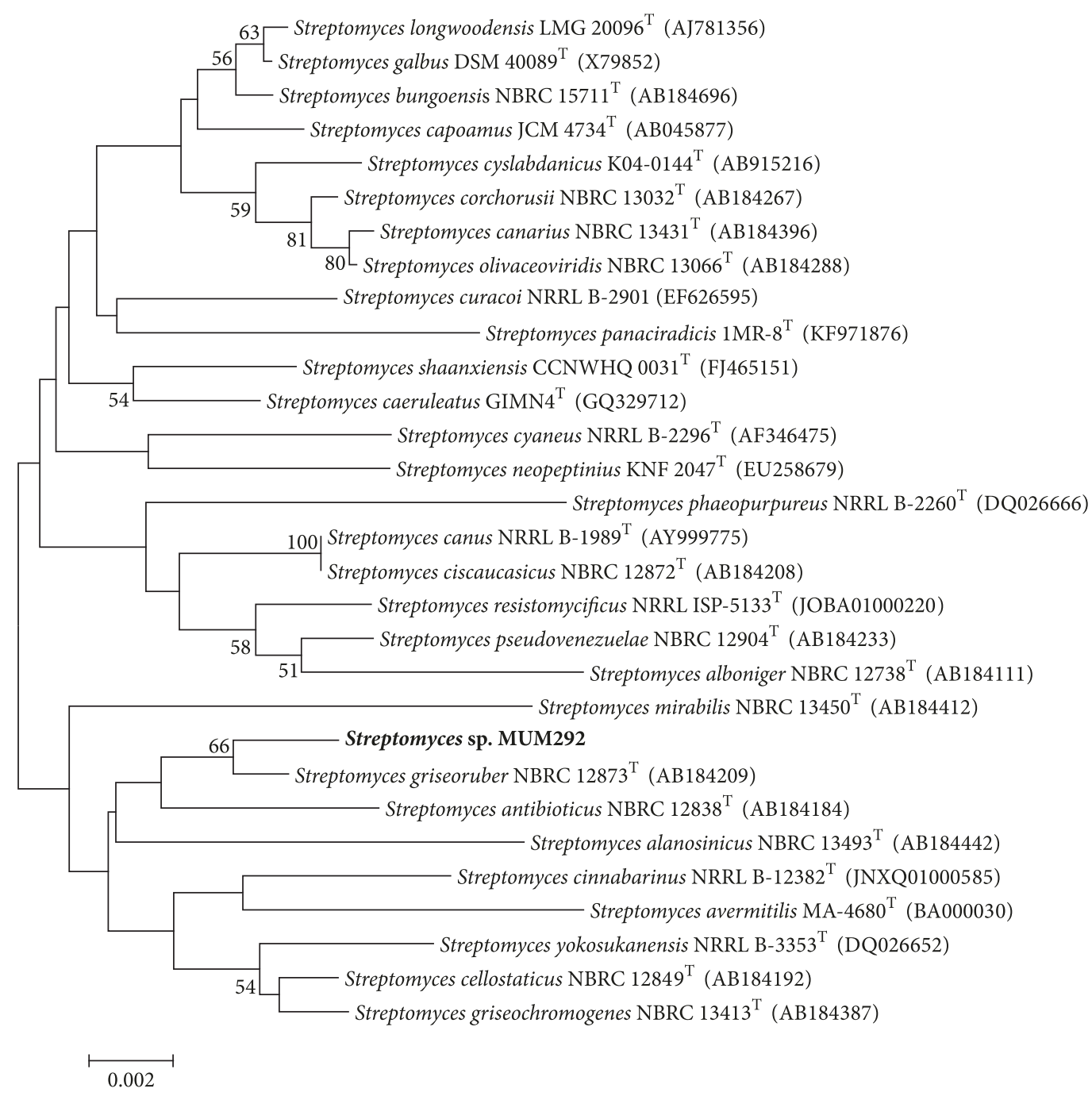

FIGURE 1: Phylogenetic tree of 16S rRNA sequences of strain MUM292 (1319 nucleotides) and representatives of some other related taxa constructed using neighbour-joining algorithm. Bootstrap values (>50\%) based on 1000 resampled datasets are shown at branch nodes. Bar, 0.002 substitutions per site.

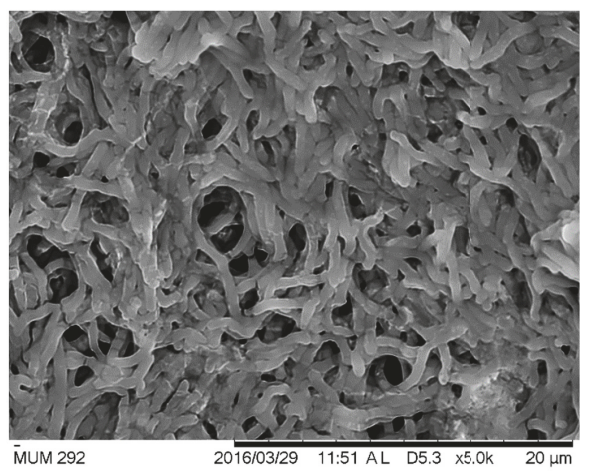

Figure 2: The scanning electron micrographs of Streptomyces sp. MUM292. The micrograph demonstrates the distinctive features of the genus Streptomyces bacteria possessing smooth filaments and branch to form a network of filaments called mycelium. not utilize the following carbon source: 3-methyl glucose, b-methyl-D-glucoside, citric acid, D-arabitol, D-fucose, D-mannitol, D-salicin, D-serine, D-sorbitol, D-turanose, gentiobiose, iosine, L-arginine, L-fucose, L-galactonic acid lactone, methyl pyruvate, mucic acid, myo-inositol, N-acetylb-D-mannosamine, N-acetyl-D-galactosamine, N-acetylneuraminic acid, and stachyose. In the chemical sensitivity test, strain MUM292 was sensitive to $1 \%$ sodium lactate but was resistant to guanidine $\mathrm{HCl}$, Niaproof 4, tetrazolium blue, and tetrazolium violet. For the antibiotic sensitivity test, it was sensitive to all the antibiotics tested except nalidixic acid. These data perhaps in future could provide extremely useful information for medium optimization in which to enhance the yield of desirable bioactive compounds.

3.3. Antioxidant Activities. Antioxidants are molecules that confer protection against oxidative stress in cell or an 
TABLE 1: The antioxidant activities demonstrated by Streptomyces MUM292 extract in different antioxidant assays.

\begin{tabular}{lcccc}
\hline $\begin{array}{l}\text { Concentration of } \\
\begin{array}{l}\text { Streptomyces sp. MUM292 } \\
\text { extract (mg/mL) }\end{array}\end{array}$ & $\begin{array}{c}\text { Antioxidant activities } \\
\text { DPPH radical scavenging } \\
\text { activity (\%) }\end{array}$ & $\begin{array}{c}\text { ABTS radical scavenging } \\
\text { activity (\%) }\end{array}$ & $\begin{array}{c}\text { Superoxide dismutase-like } \\
\text { activity (\%) }\end{array}$ & $\begin{array}{c}\text { Metal-chelating activity } \\
(\%)\end{array}$ \\
\hline 0.25 & $2.40 \pm 1.26$ & $10.64 \pm 1.27^{*}$ & $43.66 \pm 1.86^{*}$ & $14.75 \pm 0.41^{*}$ \\
0.5 & $9.09 \pm 1.40^{*}$ & $15.89 \pm 1.96^{*}$ & $56.57 \pm 1.47^{*}$ & $15.60 \pm 1.28^{*}$ \\
1 & $21.12 \pm 1.55^{*}$ & $29.76 \pm 2.60^{*}$ & $62.21 \pm 0.81^{*}$ & $16.31 \pm 2.33^{*}$ \\
2 & $29.17 \pm 6.21^{*}$ & $34.62 \pm 2.59^{*}$ & $65.14 \pm 1.76^{*}$ & $17.44 \pm 1.29^{*}$ \\
4 & $35.98 \pm 5.39^{*}$ & $67.96 \pm 2.23^{*}$ & $79.23 \pm 0.70^{*}$ & $22.54 \pm 2.37^{*}$ \\
\hline
\end{tabular}

${ }^{*}$ Statistically significant $(p<0.05)$ when compared to control (without extract).

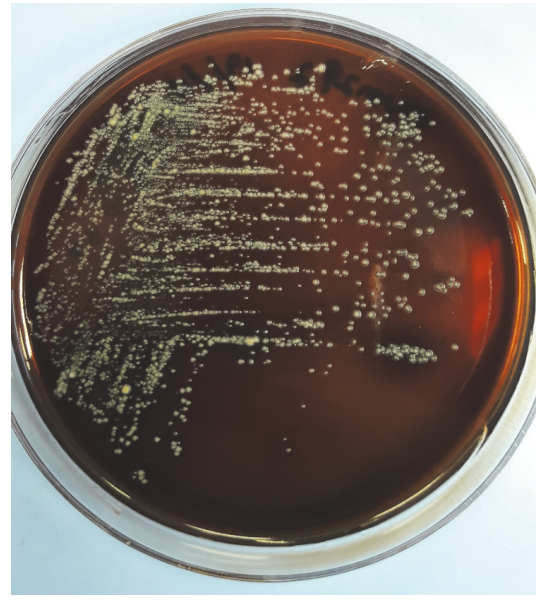

FIGURE 3: Hemolytic test of strain MUM292. The figure shows strain MUM292 grows on blood agar with no clear zone observed around the colonies, indicating strain MUM292 is negative for hemolytic activity.

organism by blocking or delaying the oxidative damage caused by the reactive oxygen species $[77,78]$. The antioxidants exert multiple mechanisms to eliminate free radicals such as inhibiting the formation of free radicals, scavenging the singlet oxygen, and chelating metal prooxidants $[79,80]$. Thus, several antioxidant activity assays were included in this study to assess the antioxidant activities of Streptomyces MUM292 extract including the DPPH radical scavenging, ABTS radical scavenging, and SOD-like and metal-chelating activities assays. Table 1 tabulates the results of the antioxidant activities of MUM292 extract. DPPH is one of the simple and rapid antioxidant activity screening assays. This assay utilizes stable free DPPH radical to evaluate the ability of a substance/compound to confer antioxidant effect through the transfer of hydrogen atoms or electron to DPPH radicals, leading to color changes which can be detected spectrophotometrically $[81,82]$. This study revealed that MUM292 exhibited significant DPPH scavenging activity of $9.09 \pm 1.40 \%$ to $35.98 \pm 5.39 \%$ at 0.5 to $4 \mathrm{mg} / \mathrm{mL}$, showing that MUM292 extract may possess the ability to donate hydrogen atom to the DPPH radical. Furthermore, this study also demonstrated that MUM292 extract is capable of scavenging $\mathrm{ABTS}^{\circ+}$ radical formed from oxidation of ABTS with potassium persulfate. The ABTS assay revealed that MUM292 extract is able to scavenge $\mathrm{ABTS}^{\bullet+}$ radical with increasing concentrations, indicated by the reduced absorbance of bluegreen color $\mathrm{ABTS}^{*+}$ upon reaction with the extract [77, 83]. The assay demonstrated MUM292 extract possessed significant ABTS radical scavenging activity $(p<0.05)$ ranging from $10.64 \pm 1.27 \%$ to $67.96 \pm 2.23 \%$ at concentrations between $0.25 \mathrm{mg} / \mathrm{mL}$ and $4 \mathrm{mg} / \mathrm{mL}$. These findings are concordant with earlier published work which reported the radicals scavenging activities of mangrove derived Streptomyces which are comparable to the antioxidant potentials of strain MUM292 [32]. The result showed that the ABTS scavenging activity of MUM292 extract is slightly higher $(34.62 \pm 2.59 \%$ at $2 \mathrm{mg} / \mathrm{mL})$ as compared to the methanolic extract of Streptomyces malaysiense sp. nov. $(27.87 \pm 2.19 \%$ at $2 \mathrm{mg} / \mathrm{mL}$ ) [32].

Superoxide anion radical $\left(\mathrm{O}_{2}{ }^{--}\right)$is a primary ROS that can generate secondary ROS which may be more potent [84]; thus the ability to scavenge superoxide anion radical to prevent further generation of other reactive oxygen intermediates is crucial. In this study, a superoxide detector, WST-1, was used to measure the SOD-like activity of MUM292 extract. Principally, the assay involves a hypoxanthine-xanthine oxidase system to generate $\mathrm{O}_{2}{ }^{--}$continuously. The WST-1, a tetrazolium salt, can be reduced by $\mathrm{O}_{2}{ }^{-{ }^{-}}$into the highly water soluble WST formazan dye [85]. The assay showed that MUM292 extract is capable of scavenging $\mathrm{O}_{2}{ }^{--}$by preventing the formation of yellow water soluble WST formazan upon the reduction by $\mathrm{O}_{2}{ }^{--}$. The assay revealed that 0.25 to $4 \mathrm{mg} / \mathrm{mL}$ of MUM292 extract exhibited significant superoxide anion scavenging activity ranging from $43.66 \pm 1.86 \%$ to $79.23 \pm 0.70 \%$. Similarly, this finding is also consistent with previous literature which demonstrated that the extracts of fermentation broth of Streptomyces sp. exhibit promising superoxide radical scavenging activities [31, 32].

The availability of free iron $\left(\mathrm{Fe}^{2+}\right)$ plays a paramount role in oxidative damage, as iron drives the Fenton reaction which involves the breakdown of $\mathrm{H}_{2} \mathrm{O}_{2}$ [86], thereby resulting in the production of hydroxyl radicals that are highly reactive toward cellular components including lipids, proteins, and DNA [87]. In the metal-chelating assay, the addition of MUM292 extract reduced the formation of purple complex between the reaction of $\mathrm{Fe}^{2+}$ ion and ferrozine. This observation implied that MUM292 extract prevented the complex formation, suggesting that the extract may contain 


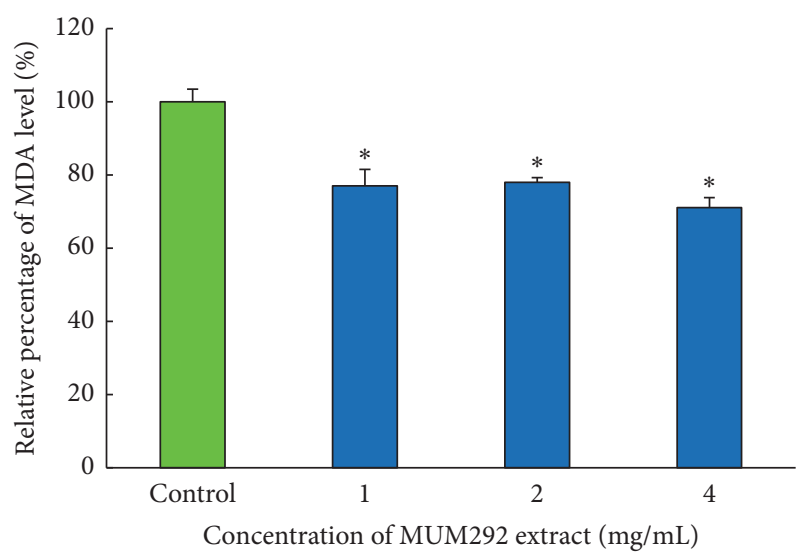

\begin{tabular}{cr}
\hline $\begin{array}{c}\text { Concentration of MUM292 extract } \\
(\mathrm{mg} / \mathrm{mL})\end{array}$ & $\begin{array}{c}\text { Percentage of } \\
\text { inhibition }(\%)\end{array}$ \\
\hline 1 & $22.96 \pm 4.50$ \\
2 & $22.00 \pm 1.24$ \\
4 & $28.94 \pm 2.69$ \\
\hline
\end{tabular}

FIGURE 4: The inhibitory effect of MUM292 extract against lipid peroxidation induced by $\mathrm{Fe}^{2+}$ in lipid-rich product. TBARS assay was used to quantify the MDA level formed. All data are presented as mean \pm SD $(n=3) . *$ indicates $p<0.05$ between control (without extract) and MUM292 extract added samples.

compounds which can chelate metal. The MUM292 extract ranging from 0.25 to $4 \mathrm{mg} / \mathrm{mL}$ was shown to exhibit significant metal-chelating activity measured from $14.75 \pm 0.41 \%$ to $22.54 \pm 2.37 \%$. This result also suggested that MUM292 extract could delay the processes of hydroxyl radical formation via Fenton reaction.

Furthermore, process of lipid peroxidation is also accelerated by transition metal by converting lipid hydroperoxides into hyperoxyl and alkoxyl radicals, subsequently resulting in the production of mutagenic substances such as MDA $[88,89]$. We investigated the effects of MUM292 extract on iron-induced peroxidation in egg yolk homogenate. The assay demonstrated that MUM292 extract inhibited the production of MDA in lipid-rich product. MUM292 extract was shown to reduce the MDA level significantly at all concentrations tested when compared to group with no MUM292 extract added (Figure 4). At $4 \mathrm{mg} / \mathrm{mL}$, MUM292 extract exerted $28.94 \pm$ $2.70 \%$ inhibition of the extent of lipid peroxidation in the lipid-rich product added with $\mathrm{Fe}^{2+}$ ion. The inhibition of iron-induced peroxidation in egg yolk homogenate further demonstrated the antioxidant potential of MUM292 extract which may be related to its metal-chelating property that stabilizes the catalytic transition metals, attenuating the formation of hydroxyl radicals. In addition, it also could be suggested that MUM292 extract may exhibit hydroxyl radical scavenging activity and consequently lead to inhibition of lipid peroxidation. Based on these findings, MUM292 extract is shown to exhibit promising antioxidant activities that hold promise for the future development of antioxidative agents which possess capability to scavenge free radicals as well as chelate metal ions.
TABLE 2: Pearson's correlation coefficients between TPC and antioxidant activities of Streptomyces MUM292 extract.

\begin{tabular}{lc}
\hline Antioxidant activities & Phenolic content \\
\hline DPPH radical scavenging activity & $r=0.935^{*}$ \\
ABTS radical scavenging activity & $r=0.942^{*}$ \\
SOD-like activity & $r=0.905^{*}$ \\
Metal-chelating activity & $r=0.937^{*}$ \\
\hline
\end{tabular}

${ }^{*}$ Correlation is significant at the 0.05 level.

3.4. Total Phenolic and Flavonoid Content of MUM292 Extract. Phenolic compounds have been the most studied phytochemicals and represent the major contributor to the antioxidant activity of many herbal plants and spices [90, 91]. Although plant has been viewed as the primary source, there are considerable evidences showing production of phenolic compounds as secondary metabolites by microorganisms, including the genus Streptomyces $[92,93]$. This study employed Folin-Ciocalteu's reagent method to estimate the total phenolic content (TPC) of MUM292 extract. Basically, the assay estimates the total concentration of compounds that possess the phenolic hydroxyl group in MUM292 extract. Folin-Ciocalteu's reagent reacts with the phenolic hydroxyl group to form blue complex that can be measured spectrophotometrically at $750 \mathrm{~nm}$. An increased absorbance of the blue complex was observed with increasing concentration of MUM292 extract, indicating that MUM292 extract contains phenolic compounds. However, negative result was noted in the flavonoid content determination assay, indicating that the MUM292 extract does not contain flavonoid or at the concentration that falls below the sensitivity of the assay. Besides that, this study also indicated that the antioxidant capacity of MUM292 is well correlated with its phenolic content. The correlation analysis revealed a strongest positive correlation between the TPC and ABTS radical scavenging activity of MUM292 extract with correlation coefficient of $r=0.942(p<0.05)$ (Table 2). Thus, the analysis suggested that the phenolic compounds present in MUM292 extract could be contributing to the total antioxidant capacity of the extract.

3.5. Detection of Bioactive Constituents in Streptomyces MUM292 Extract Using Gas Chromatography-Mass Spectrometry. To further elucidate the potential chemical compounds that may have contributed to the antioxidant properties, GCMS was used to detect the chemical compounds present in MUM292 extract. GC-MS has been widely used as the analytical tool for molecular detection and identification in drug discovery. Numerous studies also utilized GC-MS to profile the bioactive compounds present in the secondary metabolites of Streptomyces bacteria [94-96]. The results of GC-MS analysis revealed that MUM292 extract contains several groups of chemical compounds, including the pyrrole, pyrazine, phenols, and cyclic dipeptides. The identification of the chemical compounds was performed by comparing their mass spectra to standard mass spectra available in the database of W9N11 MS library. Table 3 tabulates the retention time, molecular weight, molecular formula, and biological 
TABLE 3: Chemical constituents detected in of Streptomyces sp. MUM292 extract.

\begin{tabular}{|c|c|c|c|c|c|c|c|}
\hline Number & Constituents & $\begin{array}{l}\text { Retention time } \\
(\mathrm{min})\end{array}$ & $\begin{array}{l}\text { Molecular } \\
\text { formula }\end{array}$ & $\begin{array}{c}\text { Molecular } \\
\text { weight }(\mathrm{MW})\end{array}$ & $\begin{array}{c}\text { Similarity } \\
(\%) \\
\end{array}$ & $\begin{array}{c}\text { Biological } \\
\text { activities }\end{array}$ & Ref. \\
\hline (1) & Pyrazine,methyl & 7.51 & $\mathrm{C}_{5} \mathrm{H}_{6} \mathrm{~N}_{2}$ & 94 & 86 & Antioxidant & [37] \\
\hline (2) & Pyrazine,2,5-dimethyl- & 13.489 & $\mathrm{C}_{6} \mathrm{H}_{8} \mathrm{~N}_{2}$ & 108 & 83 & Antioxidant & \\
\hline (3) & 2(5H)-Furanone & 13.844 & $\mathrm{C}_{4} \mathrm{H}_{4} \mathrm{O}_{2}$ & 84 & 80 & Antioxidant & \\
\hline (4) & Pyrazine,3-ethyl-2,5-dimethyl- & 24.224 & $\mathrm{C}_{8} \mathrm{H}_{12} \mathrm{~N}_{2}$ & 136 & 90 & Antimicrobial & [38] \\
\hline (5) & 2,3-Dimethyl-5-ethylpyrazine & 24.63 & $\mathrm{C}_{8} \mathrm{H}_{12} \mathrm{~N}_{2}$ & 136 & 87 & Antioxidant & {$[39]$} \\
\hline (6) & Benzenethanol/2-phenylethanol & 26.015 & $\mathrm{C}_{8} \mathrm{H}_{10} \mathrm{O}$ & 122 & 94 & $\begin{array}{l}\text { Antimicrobial, } \\
\text { antityrosinase }\end{array}$ & {$[40]$} \\
\hline (7) & 3-Methyl-4-phenyl-1H-pyrrole & 46.974 & $\mathrm{C}_{11} \mathrm{H}_{11} \mathrm{~N}$ & 157 & 93 & Antimicrobial & \\
\hline (8) & $\begin{array}{c}(3 \mathrm{R}, 8 \mathrm{aS})-3-\text { Methyl- } \\
1,2,3,4,5,6,7,8,8 \mathrm{a}- \\
\text { octahydropyrrolo[1,2-a]pyrazine- } \\
1,4 \text {-dione }\end{array}$ & 51.718 & $\mathrm{C}_{8} \mathrm{H}_{12} \mathrm{~N}_{2} \mathrm{O}_{2}$ & 168 & 91 & Antioxidant & {$[41]$} \\
\hline (9) & $\begin{array}{c}\text { Pyrrolo[1,2-a]pyrazine-1,4-dione, } \\
\text { hexahydro- }\end{array}$ & 53.343 & $\mathrm{C}_{7} \mathrm{H}_{10} \mathrm{~N}_{2} \mathrm{O}_{2}$ & 154 & 94 & Antioxidant & {$[42]$} \\
\hline (10) & $\begin{array}{l}\text { 1,4-Diaza-2,5-dioxo-3-isobutyl } \\
\text { bicyclo[4.3.0]nonane }\end{array}$ & 59.465 & $\mathrm{C}_{11} \mathrm{H}_{18} \mathrm{~N}_{2} \mathrm{O}_{2}$ & 210 & 72 & Antioxidant & [43] \\
\hline (11) & 9H-pyrido[3,4-b]indole & 60.392 & $\mathrm{C}_{11} \mathrm{H}_{8} \mathrm{~N}_{2}$ & 168 & 93 & Antioxidant & {$[44]$} \\
\hline (12) & $\begin{array}{l}\text { 3-Benzyl-1,4-diaza-2,5- } \\
\text { dioxobicyclo[4.3.0]nonane }\end{array}$ & 72.088 & $\mathrm{C}_{14} \mathrm{H}_{16} \mathrm{~N}_{2} \mathrm{O}_{2}$ & 244 & 99 & $\begin{array}{l}\text { Antioxidant, } \\
\text { Antimicrobial }\end{array}$ & {$[45,46]$} \\
\hline (13) & $\begin{array}{c}\text { Phenol,2,2' -methylenebis[6-(1,1- } \\
\text { dimethylethyl)-4-methyl- }\end{array}$ & 73.501 & $\mathrm{C}_{23} \mathrm{H}_{32} \mathrm{O}_{2}$ & 340 & 93 & Antioxidant & [47] \\
\hline
\end{tabular}<smiles>Cc1cnccn1</smiles>

(1)<smiles>Cc1cnc(C)cn1</smiles>

(2)<smiles>O=C1C=CCO1</smiles>

(3)<smiles>CCc1nc(C)cnc1C</smiles>

(4)<smiles>CCc1cnc(C)c(C)n1</smiles>

(5)<smiles>OCCc1ccccc1</smiles>

(6)<smiles>Cc1c[nH]cc1-c1ccccc1</smiles>

(7)<smiles>CC1NC(=O)C2CCCN2C1=O</smiles>

(8)<smiles>O=C1NCC(=O)N2CCCC12</smiles>

(9)<smiles>CC(C)CC1NC(=O)C2CCCN2C1=O</smiles>

(10)<smiles>c1ccc2c(c1)[nH]c1cnccc12</smiles>

(11)<smiles>O=C1NC(Cc2ccccc2)C(=O)N2CCCC12</smiles>

(12)<smiles>Cc1cc(Cc2cc(C)cc(C(C)(C)C)c2O)c(O)c(C(C)(C)C)c1</smiles>

(13)

FIgURE 5: Chemical structures of compounds detected in MUM292 extract.

activities of the chemical compounds. Figure 5 depicts the chemical structures detected in MUM292 extract.

According to GC-MS analysis, several groups of chemical compounds such as sulfur containing compound, pyrrole, pyrazine, cyclic dipeptides, and phenolic compounds were detected in the MUM292 extract. The chemical compounds detected in this study also have been evidenced previously in the microbial fermentation broth/extracts, including those isolated from Actinobacteria and the genus Streptomyces, for example, pyrazine,methyl- (1) [97], pyrazine,2,5-dimethyl(2) [38], 2(5H)-furanone (3) [98], pyrazine,3-ethyl-2,5dimethyl- (4) [38, 99], 2,3-dimethyl-5-ethylpyrazine (5) [99], 
2-phenylethanol (6) [100], (3R,8aS)-3-methyl-1,2,3,4,5,6,7,8,8aoctahydropyrrolo[1,2-a]pyrazine-1,4-dione (8) [35], pyrrolo[1,2-a]pyrazine-1,4-dione, hexahydro- (9) [42], 1,4-diaza2,5-dioxo-3-isobutyl bicyclo[4.3.0]nonane (10) [101], 9HPyrido[3,4-b]indole (11) [102], 3-benzyl-1,4-diaza-2,5-dioxobicyclo[4.3.0]nonane (12) [103], and phenol,2,2'-methylenebis[6-(1,1-dimethylethyl)-4-methyl- (13) [102].

The detection of phenol,2,2'-methylenebis[6-(1,1-dimethylethyl)-4-methyl- (13) as the phenolic compound in MUM292 extract was well correlated with the findings of TPC estimation that suggested the presence of phenolic compound. The detection of phenolic compounds in Streptomyces fermentation broth/extract has been evidenced in many previous investigations $[32,101]$. As a group of compounds that possess an aromatic ring bearing one or more hydroxyl groups, these phenolic compounds exert antioxidant activity via scavenging free radicals, donating atoms or electron, or chelating metal cations $[104,105]$. Thus, it could be suggested that these phenolic compounds may have contributed to the overall antioxidant capacity of MUM292 extract by scavenging radicals and chelating metal cations.

Apart from phenolic compounds, a number of the chemical compounds detected belong to the chemical group of cyclic dipeptide or 2,5-diketopiperazines (DKP) which are a group of simplest peptide derivatives found ubiquitously in nature [106]. These chemical compounds that present in MUM292 extract include (3R,8aS)-3-methyl-1,2,3,4,6,7,8,8aoctahydropyrrolo[1,2a]pyrazine-1,4-dione (8), pyrrolo[1, 2a]pyrazine-1,4-dione, hexahydro (9), 1,4-diaza-2,5-dioxo3-isobutyl bicyclo[4.3.0]nonane (10), 3-benzyl-1,4-diaza-2,5dioxobicyclo[4.3.0]nonane (12). Numerous studies have also pointed out the detection of these peptides in the fermentation culture of microorganisms [107, 108]. Previous studies also reported that these cyclic dipeptides compounds possess antioxidant activities $[42,102]$. To sum up the results of GCMS analysis, the detected chemical compounds have been evidenced in previous studies for their antioxidant properties, suggesting that the antioxidant capacity of MUM292 extract could be contributed by these chemical compounds.

\section{Conclusion}

As a whole, this study reports the isolation of an antioxidant producing Streptomyces sp. strain MUM292 from the untapped mangrove soil in Malaysia. The study showed that the MUM292 extract exhibited DPPH radical, ABTS radical, and superoxide anion radical scavenging activities. Furthermore, the metal-chelating activity of MUM292 extract also may have contributed to its ability in perturbing the process of metal-induced lipid peroxidation in lipid-rich product. The antioxidant potentials of MUM292 extract could be attributed to the presence of bioactive compounds including the cyclic dipeptides and phenolic compounds. Taken together, the present study demonstrated that mangrove derived Streptomyces, including strain MUM292, has great potential to produce antioxidative metabolite and hence merit future development of antioxidants in wide array of applications. Moreover, from an economic point of view, the cultivation of strain MUM292 could meet the growing demand of the food processing industry for the continuous supply of natural antioxidant. In fact, microbial production could serve as a sustainable source for natural antioxidants and hence it is more cost effective as compared to the chemical synthesis of synthetic antioxidants.

\section{Conflicts of Interest}

The authors declare no conflicts of interest regarding the publication of this paper.

\section{Authors' Contributions}

Loh Teng-Hern Tan, Learn-Han Lee, and Bey-Hing Goh conducted the experiments, data analysis, and manuscript writing. Bey-Hing Goh, Learn-Han Lee, Chim Kei Chan, Tahir Mehmood Khan, and Kok-Gan Chan contributed by providing vital technical support for the project and proofread the writing. Learn-Han Lee, Kok-Gan Chan, and Bey-Hing Goh contributed to the funding of the project. Learn-Han Lee and Bey-Hing Goh founded the research project.

\section{Acknowledgments}

This work was inspired by Monash PhD Research Training Module entitled "Bioprospective of Microbes with Biopharmaceutical Potential with Bioinformatics and Drug Discovery Platforms" and financially supported by the Monash University Malaysia ECR Grant (5140077-000-00), MOSTI eScience Fund (02-02-10-SF0215), University of Malaya for Research Grant (GA001-2016, GA002-2016, and PPP Grant no. PG133-2016A to Kok-Gan Chan), and External Industry Grants from Biotek Abadi Sdn Bhd (Vote no. GBA-808138 and GBA-808813).

\section{References}

[1] B. Poljsak, D. Šuput, and I. Milisav, "Achieving the balance between ROS and antioxidants: when to use the synthetic antioxidants," Oxidative Medicine and Cellular Longevity, vol. 2013, Article ID 956792, 11 pages, 2013.

[2] A. Rahal, A. Kumar, and V. Singh, "Oxidative stress, prooxidants, and antioxidants: the interplay," BioMed Research International, vol. 2014, Article ID 761264, 19 pages, 2014.

[3] T. M. Bray, "Dietary antioxidants and assessment of oxidative stress," Nutrition Journal, vol. 16, no. 7-8, pp. 578-581, 2000.

[4] F. Farinati, M. Piciocchi, E. Lavezzo, M. Bortolami, and R. Cardin, "Oxidative stress and inducible nitric oxide synthase induction in carcinogenesis," Digestive Diseases, vol. 28, no. 4-5, pp. 579-584, 2010.

[5] A. Y. Sun and Y. M. Chen, "Oxidative stress and neurodegenerative disorders," Journal of Biomedical Science, vol. 5, no. 6, pp. 401-414, 1998.

[6] A. C. Maritim, R. A. Sanders, and J. B. Watkins III, "Diabetes, oxidative stress, and antioxidants: a review," Journal of Biochemical and Molecular Toxicology, vol. 17, no. 1, pp. 24-38, 2003.

[7] A. Federico, F. Morgillo, C. Tuccillo, F. Ciardiello, and C. Loguercio, "Chronic inflammation and oxidative stress in 
human carcinogenesis," International Journal of Cancer, vol. 121, no. 11, pp. 2381-2386, 2007.

[8] B. Halliwell, M. A. Murcia, S. Chirico, and O. I. Aruoma, "Free radicals and antioxidants in food and in vivo: what they do and how they work," Critical Reviews in Food Science and Nutrition, vol. 35, no. 1-2, pp. 7-20, 1995.

[9] A. B. Falowo, P. O. Fayemi, and V. Muchenje, "Natural antioxidants against lipid-protein oxidative deterioration in meat and meat products: a review," Food Research International, vol. 64, pp. 171-181, 2014.

[10] F. Shahidi, "Antioxidants in food and food antioxidants," Molecular Nutrition Food Research, vol. 44, no. 3, pp. 158-163, 2000.

[11] B. Saad, Y. Y. Sing, M. A. Nawi et al., "Determination of synthetic phenolic antioxidants in food items using reversed-phase HPLC," Food Chemistry, vol. 105, no. 1, pp. 389-394, 2007.

[12] C. Tang, P. C.-X. Hoo, L. T.-H. Tan et al., "Golden needle mushroom: a culinary medicine with evidenced-based biological activities and health promoting properties," Frontiers in Pharmacology, vol. 7, article 474, 2016.

[13] Q. Fan, J. Ma, Q. Xu et al., "Animal-derived natural products review: focus on novel modifications and applications," Colloids and Surfaces B: Biointerfaces, vol. 128, pp. 181-190, 2015.

[14] A. Martins, H. Vieira, H. Gaspar, and S. Santos, "Marketed marine natural products in the pharmaceutical and cosmeceutical industries: tips for success," Marine Drugs, vol.12, no. 2, pp. 1066-1101, 2014.

[15] B. Chauhan, G. Kumar, N. Kalam, and S. H. Ansari, "Current concepts and prospects of herbal nutraceutical: a review," Journal of Advanced Pharmaceutical Technology and Research, vol. 4, no. 1, pp. 4-8, 2013.

[16] L. Katz and R. Baltz, "Natural product discovery: past, present, and future," Journal of Industrial Microbiology and Biotechnology, vol. 43, 2016.

[17] Z. L. Fowler and M. A. G. Koffas, "Biosynthesis and biotechnological production of flavanones: current state and perspectives," Applied Microbiology and Biotechnology, vol. 83, no. 5, pp. 799-808, 2009.

[18] S. Matassa, N. Boon, I. Pikaar, and W. Verstraete, "Microbial protein: future sustainable food supply route with low environmental footprint," Microbial Biotechnology, vol. 9, no. 5, pp. 568575, 2016.

[19] L. T.-H. Tan, K.-G. Chan, L.-H. Lee, and B.-H. Goh, "Streptomyces bacteria as potential probiotics in aquaculture," Frontiers in Microbiology, vol. 7, article 79, 2016.

[20] S.-H. Kim, H. Ko, H.-S. Bang et al., "Coprismycins A and $\mathrm{B}$, neuroprotective phenylpyridines from the dung beetleassociated bacterium, Streptomyces sp.," Bioorganic \& Medicinal Chemistry Letters, vol. 21, no. 19, pp. 5715-5718, 2011.

[21] V. M. Dan and R. Sanawar, "Anti cancer agents from microbes," in Bioresources and Bioprocess in Biotechnology, pp. 171-184, Springer, Berlin, Germany, 2017.

[22] C. Rückert, A. Albersmeier, T. Busche et al., "Complete genome sequence of Streptomyces lividans TK24," Journal of Biotechnology, vol. 199, pp. 21-22, 2015.

[23] M. J. Bibb, "Regulation of secondary metabolism in streptomycetes," Current Opinion in Microbiology, vol. 8, no. 2, pp. 208215, 2005.

[24] R. Gupta, P. Gigras, H. Mohapatra, V. K. Goswami, and B. Chauhan, "Microbial $\alpha$-amylases: a biotechnological perspective," Process Biochemistry, vol. 38, no. 11, pp. 1599-1616, 2003.
[25] A. L. Demain and S. Sanchez, "Microbial drug discovery: 80 years of progress," The Journal of Antibiotics, vol. 62, no. 1, pp. 5-16, 2009.

[26] B. B. Walters, P. Rönnbäck, J. M. Kovacs et al., "Ethnobiology, socio-economics and management of mangrove forests: a review," Aquatic Botany, vol. 89, no. 2, pp. 220-236, 2008.

[27] K. L. McKee, "Interspecific variation in growth, biomass partitioning, and defensive characteristics of neotropical mangrove seedlings: response to light and nutrient availability," American Journal of Botany, vol. 82, no. 3, pp. 299-307, 1995.

[28] J. Xu, "Bioactive natural products derived from mangroveassociated microbes," RSC Advances, vol. 5, no. 2, pp. 841-892, 2015.

[29] K. Hong, A. Gao, Q. Xie et al., "Actinomycetes for marine drug discovery isolated from mangrove soils and plants in China," Marine Drugs, vol. 7, no. 1, pp. 24-44, 2009.

[30] L.-H. Lee, N. Zainal, A.-S. Azman et al., "Diversity and antimicrobial activities of actinobacteria isolated from tropical mangrove sediments in Malaysia," The Scientific World Journal, vol. 2014, Article ID 698178, 14 pages, 2014.

[31] J. W.-F. Law, H.-L. Ser, A. Duangjai et al., "Streptomyces colonosanans sp. nov., a novel actinobacterium isolated from Malaysia mangrove soil exhibiting antioxidative activity and cytotoxic potential against human colon cancer cell lines," Frontiers in Microbiology, vol. 8, no. article 877, 2017.

[32] H.-L. Ser, U. D. Palanisamy, W.-F. Yin, K.-G. Chan, B.-H. Goh, and L.-H. Lee, "Streptomyces malaysiense sp. nov.: a novel Malaysian mangrove soil actinobacterium with antioxidative activity and cytotoxic potential against human cancer cell lines," Scientific Reports, vol. 6, Article ID 24247, 2016.

[33] N. Zainal, H.-L. Ser, W.-F. Yin, K.-K. Tee, L.-H. Lee, and K.-G. Chan, "Streptomyces humi sp. nov., an actinobacterium isolated from soil of a mangrove forest," Antonie van LeeuwenhoekJournal of Microbiology, vol. 109, no. 3, pp. 467-474, 2016.

[34] K. Biswas, J. D. Choudhury, R. Mahansaria, M. Saha, and J. Mukherjee, "Streptomyces euryhalinus sp. nov., a new actinomycete isolated from a mangrove forest," The Journal of Antibiotics, vol. 70, no. 6, pp. 747-753, 2017.

[35] L. T.-H. Tan, K.-G. Chan, T. M. Khan et al., "Streptomyces sp. MUM212 as a source of antioxidants with radical scavenging and metal chelating properties," Frontiers in Pharmacology, vol. 8, no. article 276, 2017.

[36] M. Sanjivkumar, D. R. Babu, A. M. Suganya, T. Silambarasan, R. Balagurunathan, and G. Immanuel, "Investigation on pharmacological activities of secondary metabolite extracted from a mangrove associated actinobacterium Streptomyces olivaceus (MSU3)," Biocatalysis and Agricultural Biotechnology, vol. 6, pp. 82-90, 2016.

[37] K. Yanagimoto, K.-G. Lee, H. Ochi, and T. Shibamoto, "Antioxidative activity of heterocyclic compounds found in coffee volatiles produced by Maillard reaction," Journal of Agricultural and Food Chemistry, vol. 50, no. 19, pp. 5480-5484, 2002.

[38] S. Boukaew, A. Plubrukam, and P. Prasertsan, "Effect of volatile substances from Streptomyces philanthi RM-1-138 on growth of Rhizoctonia solani on rice leaf," BioControl, vol. 58, no. 4, pp. 471-482, 2013.

[39] P. Liu, M. Huang, S. Song et al., "Sensory characteristics and antioxidant activities of maillard reaction products from soy protein hydrolysates with different molecular weight distribution," Food and Bioprocess Technology, vol. 5, no. 5, pp. 17751789, 2012. 
[40] Y.-J. Zhu, H.-T. Zhou, Y.-H. Hu et al., "Antityrosinase and antimicrobial activities of 2-phenylethanol, 2-phenylacetaldehyde and 2-phenylacetic acid," Food Chemistry, vol. 124, no. 1, pp. 298-302, 2011.

[41] K. Yamamoto, M. Hayashi, Y. Murakami et al., "Development of LC-MS/MS analysis of cyclic dipeptides and its application to tea extract," Bioscience, Biotechnology, and Biochemistry, vol. 80, no. 1, pp. 172-177, 2016.

[42] H.-L. Ser, U. D. Palanisamy, W.-F. Yin et al., "Presence of antioxidative agent, Pyrrolo[1,2-a]pyrazine-1,4-dione, hexahydro- in newly isolated Streptomyces mangrovisoli sp. nov," Frontiers in Microbiology, vol. 6, article 854, 2015.

[43] Y. Takaya, T. Furukawa, S. Miura et al., "Antioxidant constituents in distillation residue of Awamori spirits," Journal of Agricultural and Food Chemistry, vol. 55, no. 1, pp. 75-79, 2007.

[44] T. Herraiz and J. Galisteo, "Hydroxyl radical reactions and the radical scavenging activity of $\beta$-carboline alkaloids," Food Chemistry, vol. 172, pp. 640-649, 2015.

[45] K. Ström, J. Sjögren, A. Broberg, and J. Schnürer, "Lactobacillus plantarum MiLAB 393 produces the antifungal cyclic dipeptides cyclo (L-Phe-L-Pro) and cyclo (L-Phe-trans-4-OHL-Pro) and 3-phenyllactic acid," Applied and Environmental Microbiology, vol. 68, no. 9, pp. 4322-4327, 2002.

[46] M. Graz, A. Hunt, H. Jamie, G. Grant, and P. Milne, "Antimicrobial activity of selected cyclic dipeptides," Die Pharmazie, vol. 54, no. 10, pp. 772-775, 1999.

[47] X. Bai, Y. Chen, W. Chen, H. Lei, and G. Shi, "Volatile constituents, inorganic elements and primary screening of bioactivity of black coral cigarette holders," Marine Drugs, vol. 9, no. 5, pp. 863-878, 2011.

[48] Y. Takahashi, A. Matsumoto, A. Seino, Y. Iwai, and S. Omura, "Rare actinomycetes isolated from desert soils," Actinomycetologica, vol. 10, no. 2, pp. 91-97, 1996.

[49] E. T. Shirling and D. Gottlieb, "Method for characterization of Streptomyces species," International Journal of Systematic and Evolutionary Microbiology, 1966.

[50] L. H. Lee, N. Zainal, A. S. Azman et al., "Streptomyces pluripotens sp. nov., a bacteriocin-producing streptomycete that inhibits meticillin-resistant Staphylococcus aureus," International Journal of Systematic and Evolutionary Microbiology, vol. 64, no. 9, pp. 3297-3306, 2014.

[51] L.-H. Lee, N. Zainal, A.-S. Azman, N.-S. Ab Mutalib, K. Hong, and K.-G. Chan, "Mumia flava gen. nov., sp. nov., an actinobacterium of the family Nocardioidaceae," International Journal of Systematic and Evolutionary Microbiology, vol. 64, no. 5, pp. 1461-1467, 2014.

[52] J. D. Thompson, T. J. Gibson, F. Plewniak, F. Jeanmougin, and D. G. Higgins, "The CLUSTAL X windows interface: flexible strategies for multiple sequence alignment aided by quality analysis tools," Nucleic Acids Research, vol. 25, no. 24, pp. 48764882, 1997.

[53] N. Saitou and M. Nei, "The neighbor-joining method: a new method for reconstructing phylogenetic trees," Molecular Biology and Evolution, vol. 4, no. 4, pp. 406-425, 1987.

[54] K. Tamura, G. Stecher, D. Peterson, A. Filipski, and S. Kumar, "MEGA6: molecular evolutionary genetics analysis version 6.0," Molecular Biology and Evolution, vol. 30, no. 12, pp. 2725-2729, 2013.

[55] M. Kimura, "A simple method for estimating evolutionary rates of base substitutions through comparative studies of nucleotide sequences," Journal of Molecular Evolution, vol. 16, no. 2, pp. 111$120,1980$.
[56] O. Kim, Y. Cho, K. Lee et al., "Introducing EzTaxon-e: a prokaryotic 16s rRNA gene sequence database with phylotypes that represent uncultured species," International Journal of Systematic and Evolutionary Microbiology, vol. 62, no. 3, pp. 716-721, 2012.

[57] J. Felsenstein, "Confidence limits on phylogenies: an approach using the bootstrap," Evolution, vol. 39, pp. 783-791, 1985.

[58] R. M. Atlas, Handbook of Microbiological Media, CRC Press, Boca Raton, Fla, USA, 2010.

[59] E. Küster and S. Williams, "Media for the isolation of streptomycetes: starch casein medium," Nature, vol. 202, pp. 928-929, 1964.

[60] J. F. Mac Faddin, Biochemical Tests for Identification of Medical Bacteria, Williams and Wilkins Co, 1976.

[61] K. L. Kelly, "ISCC-NBC color-name charts illustrated with centroid colors," 1964.

[62] P. G. Carrillo, C. Mardaraz, S. I. Pitta-Alvarez, and A. M. Giulietti, "Isolation and selection of biosurfactant-producing bacteria," World Journal of Microbiology and Biotechnology, vol. 12, no. 1, pp. 82-84, 1996.

[63] B. Meena, L. A. Rajan, N. V. Vinithkumar, and R. Kirubagaran, "Novel marine actinobacteria from emerald Andaman \& Nicobar Islands: a prospective source for industrial and pharmaceutical byproducts," BMC Microbiology, vol. 13, no. 1, article 145, 2013

[64] W. Y. Shieh, Y.-W. Chen, S.-M. Chaw, and H.-H. Chiu, "Vibrio ruber sp. nov., a red, facultatively anaerobic, marine bacterium isolated from sea water," International Journal of Systematic and Evolutionary Microbiology, vol. 53, no. 2, pp. 479-484, 2003.

[65] L.-H. Lee, Y.-K. Cheah, S. M. Sidik et al., "Molecular characterization of Antarctic actinobacteria and screening for antimicrobial metabolite production," World Journal of Microbiology and Biotechnology, vol. 28, no. 5, pp. 2125-2137, 2012.

[66] J. P. Adjimani and P. Asare, "Antioxidant and free radical scavenging activity of iron chelators," Toxicology Reports, vol. 2, pp. 721-728, 2015.

[67] T. C. P. Dinis, V. M. C. Madeira, and L. M. Almeida, "Action of phenolic derivatives (acetaminophen, salicylate, and 5aminosalicylate) as inhibitors of membrane lipid peroxidation and as peroxyl radical scavengers," Archives of Biochemistry and Biophysics, vol. 315, no. 1, pp. 161-169, 1994.

[68] N. Dasgupta and B. De, "Antioxidant activity of Piper betle L. leaf extract in vitro," Food Chemistry, vol. 88, no. 2, pp. 219-224, 2004.

[69] Q. Zhang, J. Zhang, J. Shen, A. Silva, D. A. Dennis, and C. J. Barrow, "A simple 96-well microplate method for estimation of total polyphenol content in seaweeds," in Proceedings of the 8th International Seaweed Symposium, pp. 219-224, Springer, Berlin, Germany, 2016.

[70] T. J. Herald, P. Gadgil, and M. Tilley, "High-throughput micro plate assays for screening flavonoid content and DPPHscavenging activity in sorghum bran and flour," Journal of the Science of Food and Agriculture, vol. 92, no. 11, pp. 2326-2331, 2012.

[71] H. Supriady, M. N. A. Kamarudin, C. K. Chan, B. H. Goh, and H. A. Kadir, "SMEAF attenuates the production of pro-inflammatory mediators through the inactivation of Akt-dependent NF- $\kappa \mathrm{B}, \mathrm{p} 38$ and ERK1/2 pathways in LPS-stimulated BV-2 microglial cells," Journal of Functional Foods, vol. 17, pp. 434448, 2015. 
[72] E. Patridge, P. Gareiss, M. S. Kinch, and D. Hoyer, "An analysis of FDA-approved drugs: Natural products and their derivatives," Drug Discovery Therapy, vol. 21, no. 2, pp. 204-207, 2016.

[73] C. Vilhena and A. Bettencourt, "Daptomycin: a review of properties, clinical use, drug delivery and resistance," Mini-Reviews in Medicinal Chemistry, vol. 12, no. 3, pp. 202-209, 2012.

[74] X.-L. Li, M.-J. Xu, Y.-L. Zhao, and J. Xu, "A novel benzo[f][1,7]naphthyridine produced by streptomyces albogriseolus from mangrove sediments," Molecules, vol. 15, no. 12, pp. 9298-9307, 2010.

[75] M. P. Singh, P. J. Petersen, N. V. Jacobus, W. M. Maiese, M. Greenstein, and D. A. Steinberg, "Mechanistic studies and biological activity of bioxalomycin $\alpha 2$, a novel antibiotic produced by Streptomyces viridodiastaticus subsp. 'litoralis' LL- 31F508,' Antimicrobial Agents and Chemotherapy, vol. 38, no. 8, pp. 18081812, 1994.

[76] H.-L. Ser, J. W.-F. Law, N. Chaiyakunapruk et al., "Fermentation conditions that affect clavulanic acid production in Streptomyces clavuligerus: a systematic review," Frontiers in Microbiology, vol. 7, article 522, 2016.

[77] R. A. Apak, M. Ozyurek, K. Guclu, and E. Capanoglu, "Antioxidant activity/capacity measurement. 2. Hydrogen atom transfer (HAT)-based, mixed-mode (electron transfer (ET)/HAT), and lipid peroxidation assays," Journal of Agricultural and Food Chemistry, vol. 64, no. 5, pp. 1028-1045, 2016.

[78] B. Halliwell, "Free radicals and antioxidants-quo vadis?" Trends in Pharmacological Sciences, vol. 32, no. 3, pp. 125-130, 2011.

[79] T. P. A. Devasagayam, J. C. Tilak, K. K. Boloor, K. S. Sane, S. S. Ghaskadbi, and R. D. Lele, "Free radicals and antioxidants in human health: current status and future prospects," Journal of the Association of Physicians of India, vol. 52, pp. 794-804, 2004.

[80] V. Lobo, A. Patil, A. Phatak, and N. Chandra, "Free radicals, antioxidants and functional foods: impact on human health," Pharmacognosy Reviews, vol. 4, no. 8, pp. 118-126, 2010.

[81] P. Molyneux, "The use of the stable radical Diphenylpicrylhydrazyl (DPPH) for estimating antioxidant activity," Songklanakarin Journal of Science and Technology, vol. 26, no. 2, pp. 211-219, 2004.

[82] S. Panda, S. Das, P. Bal, S. Panda, J. Goli, and N. Mohanty, "Characterization of novel folate producing Lactobacillus rhamnosus and its appliance in fortification of ragi (Eleusine coracana) gruel," Food Bioscience, vol. 21, pp. 100-106, 2018.

[83] A. M. Campos and E. A. Lissi, "Kinetics of the reaction between 2,2I-azinobis 3-ethylbenzothiazoline-6-sulfonic acid (ABTS) derived radical cations and phenols," International Journal of Chemical Kinetics, vol. 29, no. 3, pp. 219-224, 1997.

[84] A. Bhattacharyya, R. Chattopadhyay, S. Mitra, and S. E. Crowe, "Oxidative stress: an essential factor in the pathogenesis of gastrointestinal mucosal diseases," Physiological Reviews, vol. 94, no. 2, pp. 329-354, 2014.

[85] A. V. Peskin and C. C. Winterbourn, "A microtiter plate assay for superoxide dismutase using a water-soluble tetrazolium salt (WST-1)," Clinica Chimica Acta, vol. 293, no. 1-2, pp. 157-166, 2000.

[86] E. Neyens and J. Baeyens, "A review of classic Fenton's peroxidation as an advanced oxidation technique," Journal of Hazardous Materials, vol. 98, no. 1-3, pp. 33-50, 2003.

[87] J. Prousek, "Fenton chemistry in biology and medicine," Pure and Applied Chemistry, vol. 79, no. 12, pp. 2325-2338, 2007.
[88] B. Hazra, S. Biswas, and N. Mandal, "Antioxidant and free radical scavenging activity of Spondias pinnata," BMC Complementary and Alternative Medicine, vol. 8, article 63, 2008.

[89] B. Halliwell and S. Chirico, "Lipid peroxidation: its mechanism, measurement, and significance," American Journal of Clinical Nutrition, vol. 57, no. 5, pp. 715S-725S, 1993.

[90] F. Shahidi and P. Ambigaipalan, "Phenolics and polyphenolics in foods, beverages and spices: Antioxidant activity and health effects - A review," Journal of Functional Foods, vol. 18, pp. 820897, 2015.

[91] N. Martins, L. Barros, and I. C. F. R. Ferreira, "In vivo antioxidant activity of phenolic compounds: facts and gaps," Trends in Food Science and Technology, vol. 48, pp. 1-12, 2016.

[92] T. Dey, S. Chakraborty, K. K. Jain, A. Sharma, and R. C. Kuhad, "Antioxidant phenolics and their microbial production by submerged and solid state fermentation process: a review," Trends in Food Science \& Technology, vol. 53, pp. 60-74, 2016.

[93] T. Kawahara, M. Izumikawa, M. Otoguro et al., "JBIR-94 and JBIR-125, antioxidative phenolic compounds from streptomyces sp. R56-07," Journal of Natural Products, vol. 75, no. 1, pp. 107-110, 2012.

[94] L. Elleuch, M. Shaaban, S. Smaoui et al., "Bioactive secondary metabolites from a new terrestrial streptomyces sp. TN262," Applied Biochemistry and Biotechnology, vol. 162, no. 2, pp. 579593, 2010.

[95] K. Nithya, C. Muthukumar, B. Biswas et al., "Desert actinobacteria as a source of bioactive compounds production with a special emphases on Pyridine-2,5-diacetamide a new pyridine alkaloid produced by Streptomyces sp. DA3-7," Microbiological Research, vol. 207, pp. 116-133, 2018.

[96] M. Manimaran, J. V. Gopal, and K. Kannabiran, “Antibacterial activity of Streptomyces sp. VITMK1 isolated from mangrove soil of pichavaram, Tamil Nadu, India," Proceedings of the National Academy of Sciences India Section B - Biological Sciences, vol. 87, no. 2, pp. 499-506, 2017.

[97] J. S. Dickschat, T. Martens, T. Brinkhoff, M. Simon, and S. Schulz, "Volatiles released by a Streptomyces species isolated from the North Sea," Chemistry \& Biodiversity, vol. 2, no. 7, pp. 837-865, 2005.

[98] D. Braun, N. Pauli, U. Sequin, and H. Zähner, "New butenolides from the photoconductivity screening of Streptomyces antibioticus (Waksman and Woodruff) Waksman and Henrici 1948," FEMS Microbiology Letters, vol. 126, no. 1, pp. 37-42, 1995.

[99] H.-L. Ser, L. T.-H. Tan, U. D. Palanisamy et al., "Streptomyces antioxidans sp. nov., a novel mangrove soil actinobacterium with antioxidative and neuroprotective potentials," Frontiers in Microbiology, vol. 7, article 899, 2016.

[100] K. Wilkins and C. Schöller, "Volatile organic metabolites from selected streptomyces strains," Actinomycetologica, vol. 23, no. 2, pp. 27-33, 2009.

[101] H.-L. Ser, N.-S. A. Mutalib, W.-F. Yin, K.-G. Chan, B.-H. Goh, and L.-H. Lee, "Evaluation of antioxidative and cytotoxic activities of Streptomyces pluripotens MUSC 137 isolated from mangrove soil in Malaysia," Frontiers in Microbiology, vol. 6, Article ID 01398, 2015.

[102] L. T.-H. Tan, H.-L. Ser, W.-F. Yin, K.-G. Chan, L.-H. Lee, and B.-H. Goh, "Investigation of antioxidative and anticancer potentials of Streptomyces sp. MUM256 isolated from Malaysia mangrove soil," Frontiers in Microbiology, vol. 6, article no. 1316, 2015.

[103] R. Jog, M. Pandya, G. Nareshkumar, and S. Rajkumar, "Mechanism of phosphate solubilization and antifungal activity of 
Streptomyces spp. isolated from wheat roots and rhizosphere and their application in improving plant growth," Microbiology (United Kingdom), vol. 160, no. 4, Article ID 074146, pp. 778788, 2014.

[104] S. F. Sulaiman, N. A. M. Yusoff, I. M. Eldeen et al., "Correlation between total phenolic and mineral contents with antioxidant activity of eight Malaysian bananas (Musa sp.)," Journal of Food Composition and Analysis, vol. 24, no. 1, pp. 1-10, 2011

[105] S. Yogeswari, S. Ramalakshmi, R. Neelavathy, and J. Muthumary, "Identification and comparative studies of different volatile fractions from Monochaetia kansensis by GCMS," Global Journal of Pharmacology, vol. 6, no. 2, pp. 65-71, 2012.

[106] C. Prasad, "Bioactive cyclic dipeptides," Peptides, vol. 16, no. 1, pp. 151-164, 1995.

[107] D. Vázquez-Rivera, O. González, J. Guzmán-Rodríguez et al., "Cytotoxicity of cyclodipeptides from pseudomonas aeruginosa PAO1 leads to apoptosis in human cancer cell lines," BioMed Research International, vol. 2015, Article ID 197608, 9 pages, 2015.

[108] R. Würth, F. Barbieri, and T. Florio, "New molecules and old drugs as emerging approaches to selectively target human glioblastoma cancer stem cells," BioMed Research International, vol. 2014, Article ID 126586, 11 pages, 2014. 


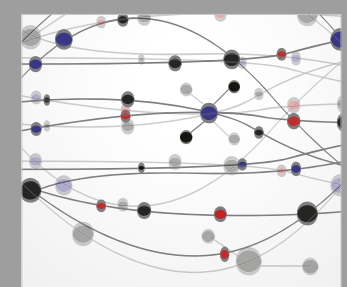

The Scientific World Journal
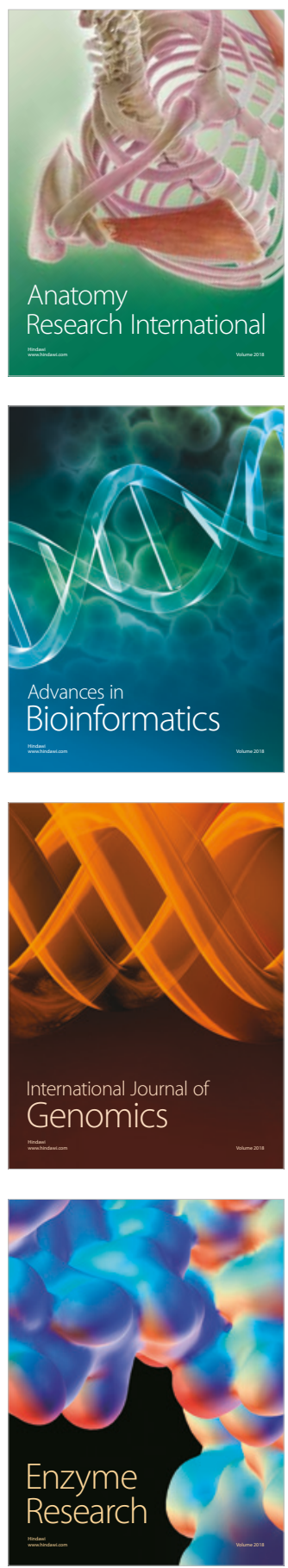
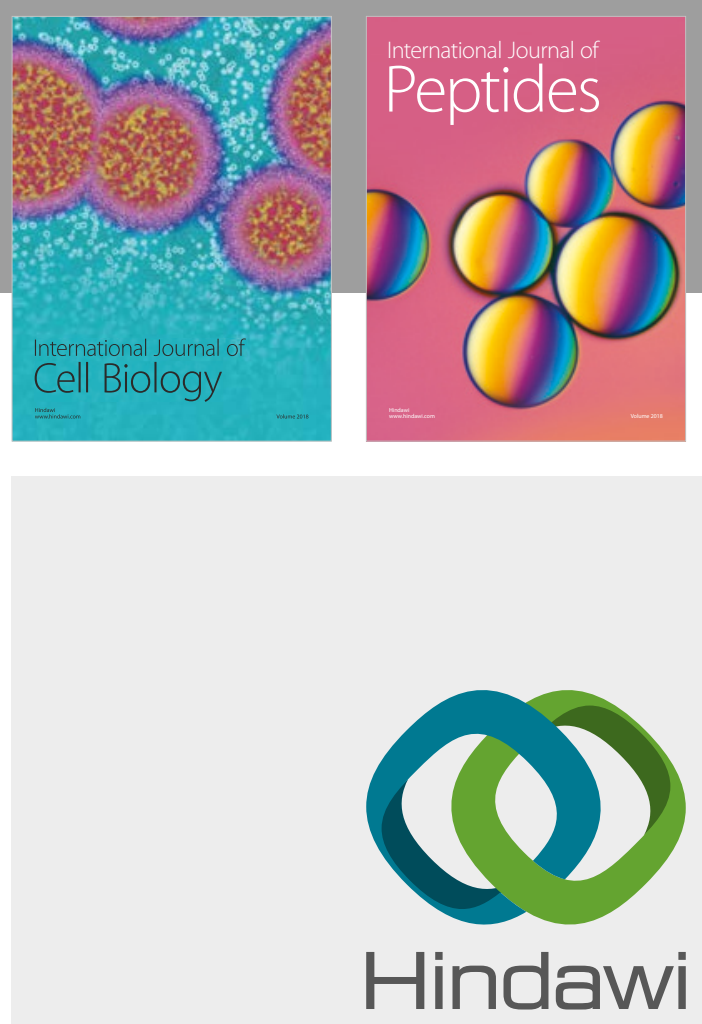

Submit your manuscripts at

www.hindawi.com
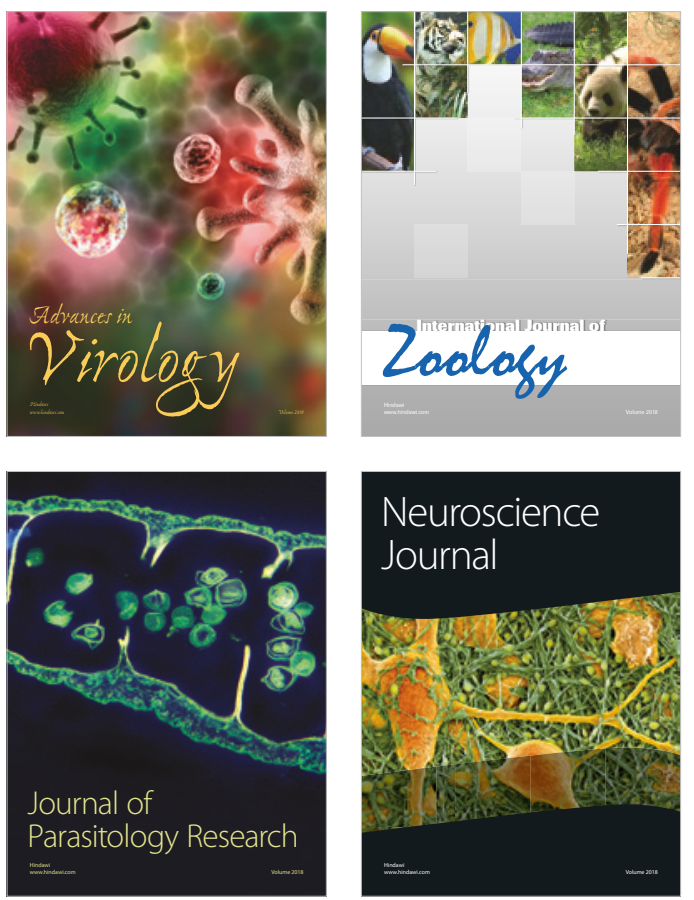
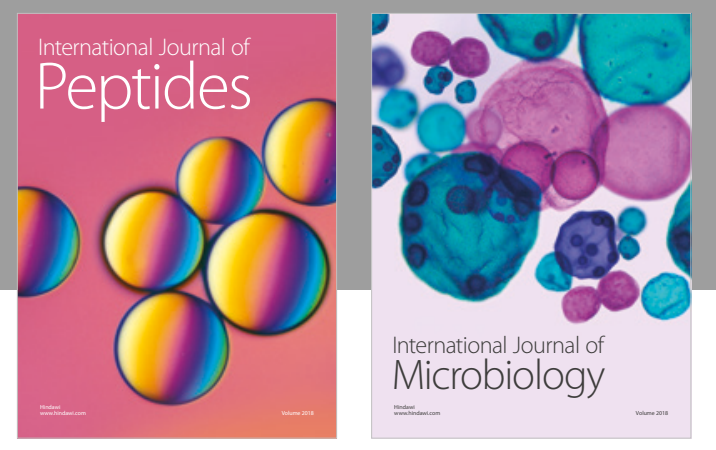

nternational Journal of Microbiology
Journal of

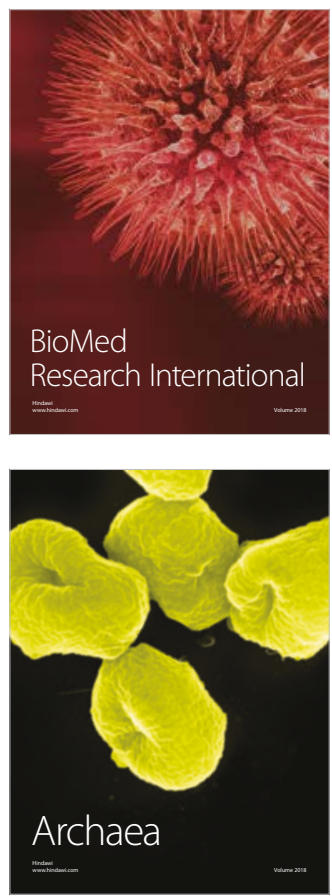